\title{
Bioactive Sphingolipids as Major Regulators of Coronary Artery Disease
}

\author{
Jae-Hwi Song ${ }^{1, \dagger}$, Goon-Tae Kim ${ }^{1, \dagger}$, Kyung-Ho Park ${ }^{2}$, Woo-Jae Park ${ }^{3, *}$ and Tae-Sik Park, \\ ${ }^{1}$ Department of Life Science, Gachon University, Sungnam 13120, \\ ${ }^{2}$ Department of Nutrition, Hallym University, Chuncheon 24252, \\ ${ }^{3}$ Department of Biochemistry, College of Medicine, Gachon University, Incheon 21999, Republic of Korea
}

\begin{abstract}
Atherosclerosis is the deposition of plaque in the main arteries. It is an inflammatory condition involving the accumulation of macrophages and various lipids (low-density lipoprotein [LDL] cholesterol, ceramide, S1P). Moreover, endothelial cells, macrophages, leukocytes, and smooth muscle cells are the major players in the atherogenic process. Sphingolipids are now emerging as important regulators in various pathophysiological processes, including the atherogenic process. Various sphingolipids exist, such as the ceramides, ceramide-1-phosphate, sphingosine, sphinganine, sphingosine-1-phosphate (S1P), sphingomyelin, and hundreds of glycosphingolipids. Among these, ceramides, glycosphingolipids, and S1P play important roles in the atherogenic processes. The atherosclerotic plaque consists of higher amounts of ceramide, glycosphingolipids, and sphingomyelin. The inhibition of the de novo ceramide biosynthesis reduces the development of atherosclerosis. S1P regulates atherogenesis via binding to the S1P receptor (S1PR). Among the five S1PRs (S1PR1-5), S1PR1 and S1PR3 mainly exert anti-atherosclerotic properties. This review mainly focuses on the effects of ceramide and S1P via the S1PR in the development of atherosclerosis. Moreover, it discusses the recent findings and potential therapeutic implications in atherosclerosis.
\end{abstract}

Key Words: Sphingolipid, Ceramide, Sphingosine 1-phosphate, Sphingosine-1-phosphate receptor, Atherosclerosis

\section{INTRODUCTION}

Atherosclerosis is the most common cause of cardiovascular disease and one of the leading causes of death worldwide (Murray and Lopez, 1997). Atherosclerotic plaques are formed in large and medium-sized arteries and are characterized by inflammation, lipid and macrophage accumulation, cell death, and fibrosis. Clinical complications occur when advanced lesions limit the blood flow or these plaques rupture, leading to unstable angina, myocardial infarction, stroke, or sudden death. The major lipids found in human atherosclerotic lesions are cholesterol, glycerophospholipids, and sphingolipids.

Recent findings show that atherosclerotic lesions contain a high concentration of sphingolipids. More than 50 years of study on human aortas obtained at autopsy revealed that the concentrations of sphingomyelin and cholesterol are high in advanced atherosclerosis; sphingomyelin can account for up to $70-80 \%$ of the phospholipids in the necrotic lesions (Smith,
1960). Similar results were obtained in a monkey model that showed higher sphingomyelin in aortic lesions and plasma of atherosclerotic monkeys compared to the control monkeys (Portman and Alexander, 1970). Such findings were essentially confirmed in a more recent study that visualized increased concentrations of cholesterol, cholesteryl esters, glycerophosphocholines, and sphingomyelins in human plaques using desorption electrospray ionization mass spectrometry scanning (Manicke et al., 2009).

The origin of atherosclerotic sphingolipids is not quite clear. In the majority of studies, it is attributed to an enhanced uptake of sphingolipid-rich lipoproteins. However, increased local sphingolipid synthesis in the atherosclerotic plaque has also been observed and is considered a contributing mechanism (Zilversmit et al., 1961; Portman and Alexander, 1970).

\section{Open Access https://doi.org/10.4062/biomolther.2020.218}

This is an Open Access article distributed under the terms of the Creative Commons Attribution Non-Commercial License (http://creativecommons.org/licenses/by-nc/4.0/) which permits unrestricted non-commercial use, distribution, and reproduction in any medium, provided the original work is properly cited.
Received Dec 3, 2020 Revised Jan 4, 2021 Accepted Jan 6, 2021 Published Online Apr 27, 2021

\section{*Corresponding Authors}

E-mail: ooze@gachon.ac.kr (ParkWJ), tspark@gachon.ac.kr (ParkTS) Tel: +82-32-899-6417 (Park WJ), +82-31-750-8824 (Park TS) Fax: +82-32-899-5678 (Park WJ), +82-31-750-8573 (Park TS)

${ }^{\dagger}$ The first two authors contributed equally to this work. 


\section{MODULATION OF CERAMIDES IN ATHEROSCLERO- SIS AND RELEVANCE AS BIOMARKERS}

Ceramides are accumulated in atherosclerotic lesions and in obesity (Schissel et al., 1996). They are involved in insulin resistance (Hla and Kolesnick, 2014), lipoprotein uptake and aggregation (Walters and Wrenn, 2008), vascular tone (Sasset et al., 2016), inflammation, oxidative stress, and apoptosis. Moreover, circulating ceramides are strongly correlated with diabetes, and some specific species have served as predictive biomarkers of future adverse cardiovascular events (Summers, 2018).

Since 2009, several small cross-sectional studies have shown that diabetic patients had elevated plasma ceramide levels (Haus et al., 2009; Boon et al., 2013; Lopez et al., 2013; Bergman et al., 2015). Lately, prospective studies based on a large population further revealed that higher concentrations of several ceramide species (e.g., C16:0, C18:0, and dihydroceramides) were associated with fasting insulin levels (Lemaitre et al., 2018; Neeland et al., 2018) and an increased future risk of diabetes in non-diabetic individuals (Wigger et al., 2017). However, after adjustment for age, sex, and race, none of the ceramide species was independently associated with the incidence of type 2 diabetes (Neeland et al., 2018).

Coronary artery disease (CAD) continues to be a leading cause of death in developed countries and starts affecting people at young ages (Lozano et al., 2012). Because of the advanced stages of atherosclerotic plaques in the blood vessels, oxygen supply to the heart is reduced. This may lead to angina pectoris, myocardial infarction, as well as sudden cardiac death. Sphingolipid metabolism has already been implicated in CAD pathogenesis, including the elevation of plasma sphingomyelin levels in CAD patients compared to the control groups (Jiang et al., 2000).

In studies on patients with CAD, the concentration of ceramide species (C16:0, C18:0, C22:0, C24:0, and C24:1) was quantified, and their ratios were used to perform risk estimation for plaque instability (Cheng et al., 2015b), adverse CAD incidents (Pan et al., 2014; Laaksonen et al., 2016; Meeusen et al., 2018), and future mortality (Tarasov et al., 2014; Yu et al., 2015; Peterson et al., 2018).

In studies on healthy individuals, serum ceramides were strongly associated with lower aerobic capacity (Fabbri et al., 2016) and could help predict adverse cardiovascular outcomes (Havulinna et al., 2016; Wang et al., 2017). Research findings from different groups were not very consistent, and the cardioprotective role of $\mathrm{C} 24$ :0-ceramides remained controversial (Sigruener et al., 2014). The inconsistency in the results of these groups might be because of differences in the patient selection methodology and/or different quantification methods.

A recent study investigated the importance of plasma ceramides as biomarkers for cardiovascular death in three independent $C A D$ cohorts. It was found that the adjusted ceramide ratios of $\mathrm{C} 16: 0 / \mathrm{C} 24: 0, \mathrm{C} 18: 0 / \mathrm{C} 24: 0$, and $\mathrm{C} 24: 1 / \mathrm{C} 24: 0$ were associated with an increased risk of cardiac death in patients with CAD (Laaksonen et al., 2016). These findings were confirmed by Meeusen et al. (2018) who found that elevation of plasma ceramide C16:0, C18:0, and C24:1 was indicative of negative cardiovascular outcomes and increased hazard ratios of 1.42-1.5 from four years (C16:0, C18:0, and C24:1) up to 18 years post-enrollment (C16:0 and $\mathrm{C} 24: 1)$. The ceramide levels were shown to be more precise than the currently used lipid prediction markers and offered a promising means of

Table 1. Clinical studies investigating the role of diverse ceramides as cardiometabolic biomarkers

\begin{tabular}{|c|c|c|c|c|}
\hline Year & Population & Correlating lipid ( $\uparrow$, higher; $\downarrow$, lower) & Clinical endpoint & Reference \\
\hline 2009 & CAD patients $(n=33)$ & $\uparrow$ Total ceramides & CAD & de Mello et al., 2009 \\
\hline 2014 & CAD patients $(n=304)$ & $\begin{array}{l}\uparrow \text { Total ceramides } \\
\uparrow \text { Sphingomyelin }\end{array}$ & Acute coronary syndrome & Pan et al., 2014 \\
\hline 2014 & CAD patients $(n=258)$ & $\uparrow \mathrm{C} 16: 0, \mathrm{C} 18: 0$ & Cardiovascular death & Tarasov et al., 2014 \\
\hline 2015 & CAD patients $(n=581)$ & $\uparrow \mathrm{C} 16: 0, \mathrm{C} 24: 0$, and $\mathrm{C} 16: 0 / \mathrm{C} 24: 0$ ratio & MACE & Cheng et al., 2015a \\
\hline 2015 & CHF patients $(n=423)$ & $\uparrow$ Total ceramides & Mortality & Yu et al., 2015 \\
\hline 2016 & $\begin{array}{l}\text { Healthy volunteers } \\
\qquad(n=433)\end{array}$ & $\begin{array}{l}\uparrow \text { C18:0, C20:0, and C24:1 } \\
\uparrow \text { Dihydroceramides }\end{array}$ & Lower aerobic capacity & Fabbri et al., 2016 \\
\hline 2016 & $\begin{array}{l}\text { Three CAD cohorts } \\
\qquad(\mathrm{n}=80,51 \text {, and } 81)\end{array}$ & $\begin{array}{l}\uparrow \mathrm{C} 16: 0, \mathrm{C} 18: 0, \mathrm{C} 24: 1 \text {, and } \mathrm{C} 16: 0 / \\
\text { C24:0 ratio }\end{array}$ & Cardiovascular death & Laaksonen et al., 2016 \\
\hline 2016 & $\begin{array}{l}\text { Heathy individuals } \\
\qquad(n=8,101)\end{array}$ & $\begin{array}{l}\uparrow \mathrm{C} 16: 0, \mathrm{C} 18: 0, \mathrm{C} 24: 1 \text {, and ratios with } \\
\text { C24:0 }\end{array}$ & Cardiovascular death & Havulinna et al., 2016 \\
\hline 2017 & PREDIMED trial $(n=980)$ & $\uparrow$ C16:0, C22:0, C24:, and C24:1 & $\begin{array}{l}\text { Non-fatal acute myocardial } \\
\text { infarction, non-fatal stroke, } \\
\text { cardiovascular death }\end{array}$ & Wang et al., 2017 \\
\hline 2018 & $\begin{array}{l}\text { Participants before } \\
\text { non-urgent coronary } \\
\text { angiography }(n=265)\end{array}$ & $\begin{array}{l}\uparrow C 16: 0, C 18: 0, C 24: 1 \text {, and ratios with } \\
\text { C24:0 }\end{array}$ & MACE & Meeusen et al., 2018 \\
\hline 2018 & $\begin{array}{l}\text { Two cohorts }(n=2,462 \\
\text { and } n=3134)\end{array}$ & $\downarrow$ C24:0/C16:0, C22:0/C16:0 ratios & $\begin{array}{l}\text { Incident CAD and total mor- } \\
\text { tality }\end{array}$ & Peterson et al., 2018 \\
\hline
\end{tabular}

CAD, coronary artery disease; CHF, chronic heart failure; MACE, major adverse cardiac events; PREDIMED, the Prevencion con Dieta Mediterranea. 


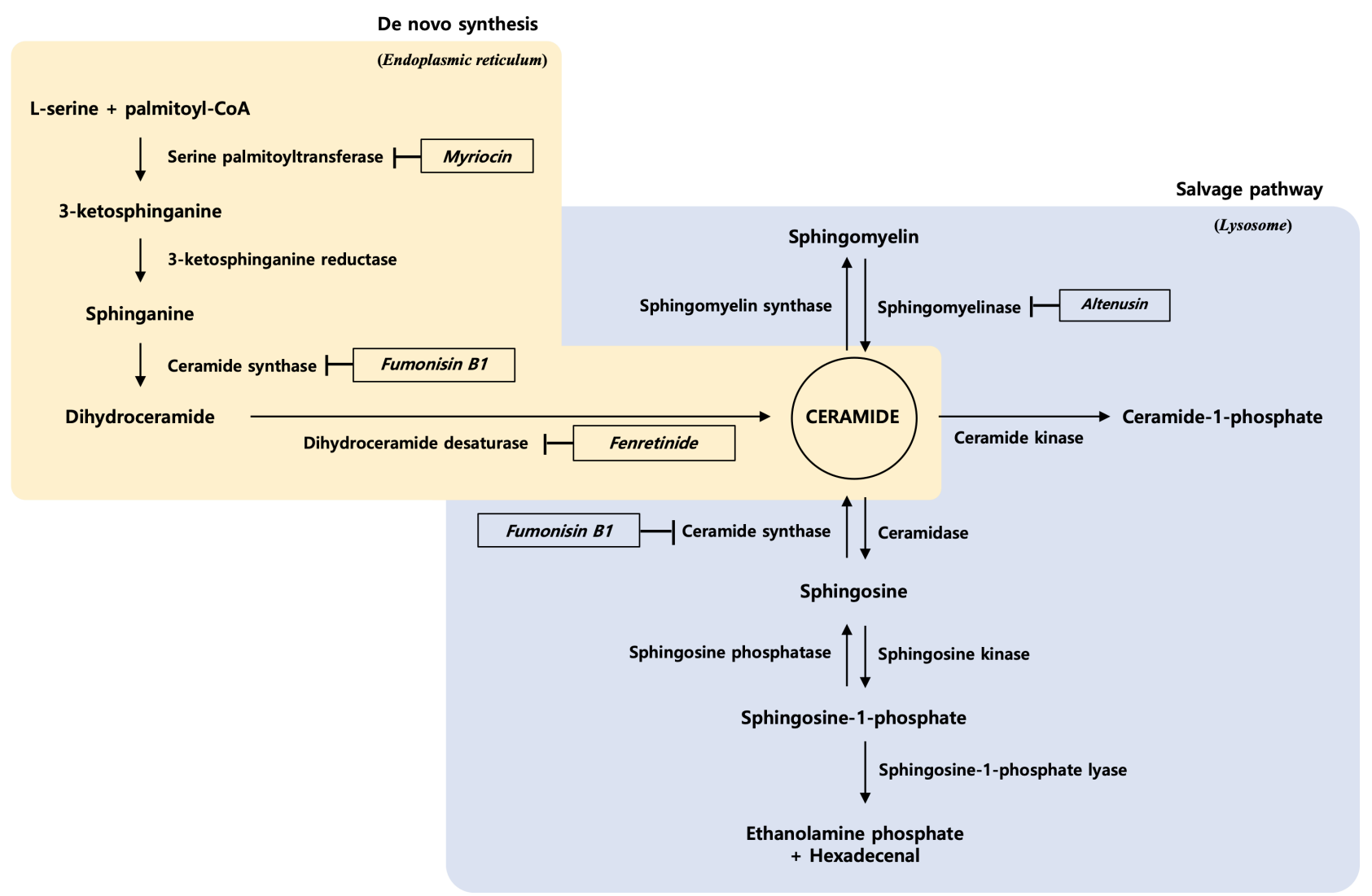

Fig. 1. Biosynthetic and salvage pathways of ceramide and sphingolipid metabolites.

identification of patients in need of more aggressive treatment. This is being tested in clinical trials in the US (Table 1). Subsequently, a ceramide plasma test for evaluation of cardiac risk was commercially released in 2016 by the Mayo Medical Laboratories (Nicholls, 2017). In general, this supportive evidence of plasma ceramides driving cardiometabolic dysfunction provided the basis for developing interventions for reduction in ceramide levels.

\section{CERAMIDE BIOSYNTHESIS PATHWAY}

Sphingolipids are based on a ceramide parent structure that is composed of a hydrophobic sphingoid backbone and a fatty acyl chain linked via an amide bond (Maula et al., 2015). Three metabolic pathways are involved in ceramide production. Biosynthetic and salvage pathways of ceramide are shown in Fig. 1.

(i) De novo ceramide synthesis begins in the cytosolic layer of the endoplasmic reticulum. It entails the condensation of the amino acid serine and palmitoyl-coenzyme A by serine palmitoyltransferase (SPT) and generates 3-ketosphinganine. 3 -Ketosphinganine is then reduced to sphinganine, an 18-carbon backbone, via 3-ketosphinganine reductase (KSR). Finally, the sphinganine gets $\mathrm{N}$-acylated by the ceramide synthases (CerS), generating dihydroceramide, which is subsequently converted into ceramide by dihydroceramide desaturase (DES) (Castro et al., 2014). The de novo synthetic pathway is the major source of ceramide in cells. All eukaryotic cells have the capacity to produce sphingolipids in this manner.

(ii) A catabolic pathway occurs in the lysosomes that involves the hydrolysis of sphingomyelin by sphingomyelinase (SMase) and catabolism of glycosphingolipids by glycosidases that hydrolyze glycosidic bonds (Maceyka and Spiegel, 2014).

(iii) A salvage pathway generates ceramides by recycling sphingosine via CerS. Ceramidase (CDase) catalyzes the hydrolysis of ceramide to generate sphingosine (Galadari et al., 2015). At least half of the sphingosine enters this reutilization pathway and plays an important role in sphingolipid homeostasis (Maceyka and Spiegel, 2014).

\section{THE ROLE OF CERAMIDES IN ATHEROSCLEROSIS}

\section{Serine palmitoyltransferase (SPT)}

SPT catalyzes the first reaction that condenses serine with palmitoyl-coenzyme A to produce 3-ketosphinganine (Hanada, 2003). Two physically associated gene products (SPTLC1 and SPTLC2) are necessary for the enzyme activity. A putative third subunit has recently been identified in both yeast (Gable et al., 2000) and mammals (Hornemann et al., 2006). In all organisms, the enzyme is highly selective for saturated fatty acyl-CoA molecules containing 16 carbons. The rate of this reaction is influenced largely by the availability of the free fatty acid (FFA) substrate (Merrill, 2002). This explains 
the mechanism by which only saturated fats (and not the unsaturated ones) drive the synthesis of sphingolipids (Chavez et al., 2003; Holland et al., 2007). Inhibitors of SPT include the highly specific sphingofungins, lipoxamycin, and myriocin and the relatively less specific $\beta$-chloroalanine and cycloserine (Delgado et al., 2006).

Myriocin, a commonly used SPT inhibitor (also known as thermozymocidin) inhibits the first step in the de novo synthesis pathway. It is derived from a traditional Chinese medicine called Isaria sinclairii, which is classified as a fungal species. Park et al. first investigated the beneficial effects of myriocin against the development of atherosclerosis in $\mathrm{ApoE}^{-/-}$mice (Park et al., 2004). Myriocin administration could dramatically prevent the progression of atherosclerotic lesions and even regress the pre-existing plaques and lower the plasma levels of total cholesterols, triglycerides, ceramides, sphingomyelins, S1P, sphingosine, and glycosphingolipids (Hojjati et al., 2005; Park et al., 2006; Glaros et al., 2007; Park et al., 2008). Besides, myriocin was found to improve insulin sensitivity (Dekker et al., 2013; Campana et al., 2018; Zabielski et al., 2019), ameliorate hepatic lipid accumulation, and further reverse non-alcoholic fatty liver disease (NAFLD) (Kurek et al., 2014; Kasumov et al., 2015). Because myriocin inhibits the initial step in the synthesis of a number of sphingolipids, the identity of the critical species involved is unknown. Nevertheless, experimental results supported the hypothesis that SPT inhibition could be a novel therapeutic target in atherosclerosis and metabolic diseases.

\section{Ceramide synthases (CerS)}

CerS acylates sphinganine to produce dihydroceramide (Pewzner-Jung et al., 2006). Recent studies indicate that a large family of CerS isoforms exists, each demonstrating selectivity for particular fatty acyl-CoA substrates (Pewzner-Jung et al., 2006). Because of the existence of multiple specific enzymes catalyzing this reaction, it is tempting to speculate that individual ceramide subspecies may have distinct biological functions. However, this assumption has not yet been confirmed through experimentation. A number of fungal metabolites have been shown to inhibit this step; fumonisin B1 is the most widely used reagent among these (Delgado et al., 2006).

Six fatty acyl-selective CerSs (CerS1-6) exist in mammals and are distributed in distinct tissues (Park et al., 2014). The regulation of CerSs is elaborate at multiple levels, and the enzyme activity may not be consistent with mRNA or protein expression levels. Mutations in the CerSs genes or deregulation of the contents and enzyme activities of CerSs are all correlated with human disease. Over the past few years, each CerS knockout was established in mice. It showed that specific CerS deactivation may cause serious impacts and may be lethal, such as the CerS1-null mice exhibiting Purkinje cell death (Zhao et al., 2011), CerS2-null mice generating myelin sheath defects and hepatocellular carcinomas (Imgrund et al., 2009), CerS3-null mice dying shortly after birth (Jennemann et al., 2012), and CerS4-null mice developing alopecia (Ebel et al., 2014). CerS5/6-null mice showed a relatively milder phenotype that presented some behavioral abnormalities (Ebel et al., 2013).

Turpin et al. (2014) identified that only CerS6 expression was positively correlated with obesity. Further, they generated conventional CerS6-deficient mice as well as specific brown adipose tissue and liver CerS6 deletion mice. Thus, they dem- onstrated that CerS6 ablation could up-regulate $\beta$-oxidation and increase lipid utilization (Turpin et al., 2014). Conversely, overexpression of CerS6 increases the levels of a specific species, known as C16:0 ceramides, in the mitochondrial membranes, where they interact with the mitochondrial fission factor (Mff) and thereby promote mitochondrial fragmentation (Hammerschmidt et al., 2019). However, silencing of this Mff in mice with simultaneous overexpression of CerS6 prevented mitochondrial fragmentation and glucose intolerance, despite increased levels of the C16:0 ceramides (Hammerschmidt et al., 2019).

However, conclusive data showing that targeting specifically unique CerS could benefit atherosclerotic degression are not available. Moreover, pharmacological inhibitors with high degree of selectivity for any particular CerS are not yet available. Given that CerS6 inhibition is beneficial for obesity and diabetes, it will probably restrain atherosclerosis development. Nevertheless, further novel studies are required to provide favorable evidence about this assumption.

\section{Dihydroceramide desaturases (DES)}

DES oxidizes inactive dihydroceramide into active ceramide. Two isoforms have been identified. Dihydroceramide desaturase 1 (DES1) inserts a key double bond in most peripheral tissues (Omae et al., 2004), whereas the DES2 isoform preferentially produces phytosphingolipids and is largely restricted to the gut and the kidneys (Omae et al., 2004). The anticancer and antidiabetic agent fenretinide (Zheng et al., 2006; Kraveka et al., 2007), a cyclopropene-containing sphingolipid (termed GT11), and a rationally designed compound (termed XM642) are inhibitors of this enzyme (Delgado et al., 2006; Munoz-Olaya et al., 2008).

In the last few years, multiple publications have shown that dihydroceramides are implicated in a far wider spectrum of biological functions than previously thought (Rodriguez-Cuenca et al., 2015). Heterozygous deletion of Des1 in mice was also demonstrated to prevent diet-induced vascular dysfunction and hypertension in mice (Zhang et al., 2012). Importantly, pharmacological inhibition of DES1 protected humans from obesity and insulin resistance. The most notable inhibitory compound is fenretinide, which has been tested in several clinical trials (Mody and Mcllroy, 2014). Fenretinide treatment could positively balance the metabolic profile by improving insulin sensitivity in overweight premenopausal women (Johansson et al., 2008). Moreover, long-term therapy with fenretinide could alleviate diet-induced adiposity and dyslipidemia and prevent hepatic steatosis in mice (Preitner et al., 2009; Bikman et al., 2012; Koh et al., 2012).

A recent study by Chaurasia et al. (2019) established the importance of ceramides through the genetic manipulation of Des1 in mice. An inducible whole-body deletion of Des 1 in both lean and obese (leptin-deficient) mice altered the energy balance. Finally, an adeno-associated vector containing a small hairpin RNA, targeting the Des1 mRNA for degradation, improved the metabolic measures in mice that either were already obese or were of normal weight but subsequently administered a high-fat diet. An added benefit of preventing obesity was observed in the latter group of mice. In summary, the deletion of Des1 improved insulin signaling and mitochondrial function and decreased lipogenesis and lipid uptake. Altogether, although there was no direct evidence of inhibition of Des1 preventing atherosclerosis, it is reasonable to hypothesize 
DES1 as an effective target for normalizing vascular homeostasis by controlling ceramide production.

\section{Ceramidases (CDase)}

CDase deacylates ceramide to produce sphingosine that can, in turn, be phosphorylated by sphingosine kinase to produce sphingosine 1-phosphate (S1P). S1P often opposes the ceramide action, leading researchers to propose the existence of a ceramide:S1P rheostat that controls cellular responses (Hait et al., 2006). Ceramidases, which can sometimes catalyze the reverse reaction to convert sphingosine back into ceramide, can be distinguished by their $\mathrm{pH}$ optima (Kolesnick, 2002). Collectively, ceramidases are ubiquitously distributed throughout the cellular membranes and also secreted into the extracellular milieu.

Inhibitors targeting the process of ceramide biosynthesis are potential means for the treatment of metabolic syndrome. Hence, we can presume that promoting ceramide degradation may provide similar benefits. Deacylation of ceramide species is initiated by a family of enzymes called the CDase. Chavez et al. (2005) demonstrated that overexpression of CDase negated the inhibitory effects of exogenous free fatty acids on muscle insulin sensitivity by blocking ceramide accumulation in vitro. Holland et al. (2011) found that adiponectin, a protein hormone with antidiabetic and cardioprotective properties, could stimulate CDase activity and further lower the concentration of cellular ceramides. CDase was found to have some homology with the adiponectin receptors, AdipoR1 and AdipoR2. From in vivo studies, it was found that targeted induction of ceramide degradation in adipose tissue or liver by overexpressing transgenic CDase was sufficient to recapitulate most adiponectin actions (Xia et al., 2015). Moreover, overexpression of AdipoR1 or AdipoR2 in either the adipocyte or hepatocyte resulted in enhanced CDase activation, improved hyperglycemia and glucose intolerance, and inhibition of hepatic steatosis (Holland et al., 2017). Together, adiponectin exerted its metabolic improvement functions through CDase signaling (Reibe-Pal and Febbraio, 2017). These findings support the strategy of CDase replacement as a potential treatment for atherosclerosis.

\section{Sphingomyelinase (SMase)}

SMases are also known to be implicated in atherogenesis. Mice deficient in the acid sphingomyelinase (ASMase) displayed $40-50 \%$ reduction in early foam cell formation and $87 \%$ reduction in lipoprotein trapping in $\mathrm{ApoE}^{-/-}$mice (Devlin et al., 2008). ASMase can be secreted and further activated after binding to the matrix (collagen, fibronectin, laminin, and heparin), (Marathe et al., 1999). Furthermore, ASMase not only regulated inflammation and apoptosis in the macrophages (Jin et al., 2013; Zhao et al., 2016), but also played an important role in cholesterol trafficking and efflux (Jin et al., 2013). Inhibition and deficiency of neutral sphingomyelinase (NSMase) (by GW4869) also decreased the inflammatory response by oxidized LDL and had significantly less ICAM1, VCAM1, MCP-1 expressions, which are chemo-attractants of macrophage/monocytes, leading to reduction in atherosclerosis development (Lallemand et al., 2018). The deficiency of sphingomyelin synthases 1 and 2 (SMS1, SMS2) prevented atherogenesis (Liu et al., 2009; Li et al., 2012). Mice deficient in SMS1 had attenuated toll-like receptor 4 (TLR4)-mediated NF- $\mathrm{KB}$ activation. SMS2-deficient mice showed reduced cho- lesterol efflux and reduction in the levels of interleukin- 6 and tumor necrosis factor $\alpha$. Further, SMS2-deficient mice had significantly less necrotic core area, less macrophage infiltration, and more collagen content in the atherosclerotic lesions. SMS2 deficiency attenuated NF- $\mathrm{BB}$ activation, suggesting that SMS2 plays a critical role in inflammation (Hailemariam et al., 2008). Conversely, SMS2 overexpression by AAV (adenoassociated virus) increased the atherosclerotic lesions and inflammation (Wang et al., 2011; Zhao et al., 2012) SMS1 and SMS2 overexpression by AAV increased non-HDL cholesterol and non-HDL-SM, serum ApoB, and hepatic SR-B1 expression, suggesting increased atherogenic potential (Dong et al., 2006). Taken together, even though the protective mechanisms in atherogenesis are not understood, SMase and SMS could be therapeutic strategies against atherosclerosis generation.

\section{THE ROLE OF S1P IN ATHEROSCLEROSIS}

\section{S1P}

S1P is a bioactive lipid, primarily carried by apolipoprotein M (apoM) on HDL and signals its G-protein-coupled receptors, named S1PR1-5 (Hla and Dannenberg, 2012). S1P is degraded by two pathways: dephosphorylation by S1P phosphatases (SPP1/2) and irreversible cleavage by S1P lyase (SPL). The roles of S1P in the fields of atherosclerosis have been demonstrated in many elegant reports. In general, S1P possesses protective roles in atherosclerosis, but it can also exert harmful effects during the pathogenesis of atherosclerosis.

\section{S1P receptors}

Various reports have investigated the physiological roles of S1P and S1P receptors in the pathogenesis of atherosclerosis using animal experiments. For example, S1PR3 knockout mice exhibited resistance to the protective properties of $\mathrm{HDL}$ or S1P in a model of coronary infarction (Theilmeier et al., 2006), while increased recruitment of monocyte/macrophage and neointima formation was caused by carotid artery ligation in S1PR3 knockout mice (Keul et al., 2011). S1PR2 knockout mice developed atherosclerotic lesions to a lesser degree when they had a background of apoE deficiency and reduced macrophage recruitment (Skoura et al., 2011). Although S1PR1 knockout mice are embryonically lethal (Liu et al., 2000), pharmacological experiments showed that an S1PR1 agonist protected the LDL receptor knockout mice from atherosclerosis (Poti et al., 2013). S1P preserves the endothelium via S1PR1/3 (Kurano and Yatomi, 2018), inhibits the migration of smooth muscle cells via S1PR2, and shows anti-inflammatory properties via S1PR4 (Fettel et al., 2019). However, S1P also promotes inflammatory monocyte/macrophage recruitment through S1PR2/3 (Michaud et al., 2010; Keul et al., 2011). Together, these reports suggest that S1PR1 and S1PR3 mainly exert anti-atherosclerotic properties, while S1PR2 exerts pro-atherosclerotic properties. Further studies are required to investigate the involvement of S1P receptors in the pathogenesis of atherosclerosis.

The S1P receptor modulator FTY720 was approved by the FDA, USA and is now used for treating multiple sclerosis (Keul et al., 2007; Wang et al., 2014). It was successful in reducing atherosclerotic lesions, macrophage infiltration, and collagen content (Keul et al., 2007). FTY720 treatment also showed 
a reduction in the infarct size in cardiac ischemia-reperfusion injury (Wang et al., 2014). It increased the levels of NiemannPick C1 protein and ATP-binding cassette transporter A1 protein, further increasing the efflux of endosomal cholesterol to apolipoprotein A1. Moreover, it decreased the cholesterol toxicity in macrophages by reducing the delivery of cholesterol to the ER (Blom et al., 2010).

\section{Sphingosine kinases}

Regarding the effects of S1P levels, a sphingosine kinase (SphK) inhibitor has been demonstrated to suppress atherosclerotic lesions in LDL receptor knockout mice that were fed a high cholesterol diet, but not in mice that were fed normal chow (Poti et al., 2015). Contrary to the possible anti-atherosclerotic properties of lowering S1P using an SphK inhibitor, overexpression of apoM in the LDL receptor-knockout mice and apoE-knockout mice protected the mice against atherosclerosis, although the association with S1P was not mentioned (Wolfrum et al., 2005). These results suggest that S1P bound to apoM might possess distinct properties from S1P bound to albumin in the pathogenesis of atherosclerosis.

\section{Clinical correlation of plasma S1P and CAD}

Several clinical data reported that plasma S1P concentrations are negatively associated with the prevalence and severity of CAD and myocardial infarction. At present, only four studies have shown an association between plasma S1P levels and atherosclerotic diseases (Knapp et al., 2009; Sattler et al., 2010; Knapp et al., 2013; Sattler et al., 2014) (Table 2). Among them, Sattler et al. (2010) reported that S1P uncoupled from HDL was more prevalent than the bound form in subjects with myocardial infarction and stable angina. This supports the idea that S1P bound to apolipoprotein M (apoM) possesses anti-atherosclerotic properties while S1P bound to albumin might somehow be involved in the harmful effects of S1P. Other clinical studies have also demonstrated that plasma S1P levels were lower in patients with myocardial infarction (Knapp et al., 2009, 2013) and that S1P bound to HDL might predict the severity of coronary heart disease (Sattler et al., 2014). Although an association between the total apoM level and atherosclerosis is not shown (Takahashi et al., 2017), apoM polymorphism is reported to be associated with atherosclerosis (Jiao et al., 2007; Xu et al., 2008). Further studies are required to elucidate the involvement of apoM in human atherosclerosis.

\section{THE ROLE OF OTHER SPHINGOLIPIDS IN ATHEROSCLEROSIS}

\section{Glycosphingolipids and atherosclerosis}

Glycosphingolipids are extremely diverse. They are composed of hydrophobic ceramide scaffolds and hydrophilic sugar chains. Their glycosyl groups are different, such as Dglucose, D-galactose, D-acetylglucosamine, D-acetylgalactosamine, L-fucose, D-mannose, and sialic acid. Sphingoglycolipids are generally divided into cerebrosides, sulfatides, globosides, and gangliosides. According to the number of glycosides, they are divided into monohexosylceramide (MHC), dihexosylceramide (DHC), trihexosylceramide (THC), and tetrahexosylceramide.

The following observations led to the association of glycosphingolipids with atherosclerosis: (a) gangliosides (Breckenridge et al., 1975), especially ganglioside GM3, glucosylceramide (GluCer), and lactosylceramide (LacCer) accumulate in the atherosclerotic plaques (Mukhin et al., 1995; Bobryshev et al., 1997; Chatterjee et al., 1997; Gracheva et al., 2009). (b) GluCer and LacCer not only stimulate the proliferation of aortic smooth muscle (Bhunia et al., 1997), but also suppress apoE production in macrophages and cholesterol-loaded foam cells (Garner et al., 2002). (c) LacCer stimulates the recruitment of monocytes to the endothelium (Gong et al., 2004). (d) GM3 stimulates monocyte differentiation into macrophages and increases the uptake of LDL in macrophages (Prokazova et al., 1991; Gracheva et al., 2009). Recently, specific plasma glycosphingolipids such as DHC, GluCer, and LacCer were identified as discriminatory risk-associated lipids for unstable CAD and CAD mortality (Meikle et al., 2011; Tarasov et al., 2014; Cheng et al., 2015a). Li et al. (2014) successfully separated the isomer pair of galactosylceramide (GalCer) and GluCer. They showed that plasma GalCer levels, and not GluCer levels, had increased in atherosclerotic patients. In animal studies, inhibition of glycosphingolipid synthesis inhibited atherosclerosis development (Bietrix et al., 2010; Chatterjee et al., 2014). Numerous distinct glycosphingolipid species exist, making it difficult to determine the one that is critical for the

Table 2. Clinical studies investigating the diverse roles of S1P as a cardiometabolic biomarker

\begin{tabular}{|c|c|c|c|c|}
\hline Year & Population & $\begin{array}{c}\text { Correlating lipid } \\
(\uparrow, \text { higher; } \downarrow \text {, lower })\end{array}$ & Clinical end point & Reference \\
\hline 2003 & CAD patients $(n=318)$ & $\uparrow \mathrm{S} 1 \mathrm{P}$ & CAD & Deutschman et al., 2003 \\
\hline 2009 & MI patients $(n=22)$ & $\downarrow \mathrm{S} 1 \mathrm{P}$ & MI & Knapp et al., 2009 \\
\hline 2010 & CAD patients $(n=178)$ & $\begin{array}{l}\downarrow \text { HDL-bound S1P } \\
\uparrow \text { non HDL-bound S1P }\end{array}$ & $\mathrm{CAD}$ and $\mathrm{MI}$ & Sattler et al., 2010 \\
\hline 2011 & $\mathrm{CCHS}(n=95)$ & $\begin{array}{l}\downarrow \text { HDL-bound S1P } \\
\downarrow \text { Dihydro-S1P and ceramide (C24:1) }\end{array}$ & CAD & Argraves et al., 2011 \\
\hline 2013 & MI patients $(n=32)$ & $\downarrow \mathrm{S} 1 \mathrm{P}$ & MI & Knapp et al., 2013 \\
\hline 2014 & CAD patients $(n=59)$ & $\downarrow$ HDL-bound S1P & CAD & Sattler et al., 2014 \\
\hline 2017 & $\begin{array}{l}\text { Patients with ischemic } \\
\text { heart disease }\end{array}$ & $\downarrow$ S1P and sphingomyelins & $\begin{array}{l}\text { Reduced left ventricular } \\
\text { ejection fraction }\end{array}$ & Polzin et al., 2017 \\
\hline
\end{tabular}

CAD, coronary artery disease; CCHS, Copenhagen City Heart Study; MI, myocardial infarction. 
onset of atherosclerosis. Therefore, inhibition of glycosphingolipid synthesis may be an effective approach for the treatment of atherosclerosis.

\section{CONCLUSION}

Sphingolipids are a large class of lipids with varied structural and signaling roles. Their levels are increased in atherosclerotic lesions (Smith, 1960; Zilversmit et al., 1961; Portman and Alexander, 1970; Manicke et al., 2009). Researchers have significantly improved knowledge of the diverse mediators of obesity-related diseases. Several enzymes involved in the different pathways of ceramide metabolism, such as SPT, CerS family, or the DES, can be potential targets to manipulate ceramide generation. Nowadays, genetic inhibition of enzymes that control the global ceramide synthesis is more often considered an attractive therapeutic target for the treatment of metabolic diseases and obesity (Adams et al., 2004; Gault et al., 2010; Chavez et al., 2012; Chaurasia and Summers, 2015). It is worth noting that ceramides participate in various cellular processes, so there exists a risk of negative effects of the inhibition of systemic sphingolipid synthesis. It seems to be extremely important to determine the enzymes in the ceramide pathway that participate in metabolic disease progression.

New data suggest a pro-atherogenic role for sphingolipids that might be specifically significant in the scenario of the metabolic syndrome. Sphingolipid metabolism can be regulated at the level of LDL absorption, lipoprotein transport, de novo synthesis, and turnover. Increased levels of the sphingolipids in the plasma and the vascular wall are strongly associated with atherosclerosis in the patients as well as experimental models. Intracellular ceramides may exert their pro-atherogenic activities via the stimulation of apoptosis, stress signaling, and cholesterol synthesis. The ceramide derivative S1P may, in part, counterbalance the ceramide activities via antiapoptotic and pro-proliferative signaling. S1P itself exists in the extracellular form (primarily in association with HDL) and as an intracellular messenger that may exert both pro- and antiatherogenic signaling. Various targets along the sphingolipid pathways provide numerous opportunities for drug discovery. In future, those efforts may yield compounds that can be used as a combination therapy with lipid-lowering agents and/or as a stand-alone therapy to prevent the progression of metabolic syndrome towards atherosclerosis.

\section{CONFLICT OF INTEREST}

The authors declare that they have no conflicting interest.

\section{ACKNOWLEDGMENTS}

This research was supported by the Gachon University research fund of 2019 (GCU-2019-0705) and the National Research Foundation of Korea (NRF) funded by the Korean government (MSIP) to T.S.P. (2020R1A2C2012833) and W.J.P. (2016R1D1A1B04930619).

\section{REFERENCES}

Adams, J. M., 2nd, Pratipanawatr, T., Berria, R., Wang, E., DeFronzo, R. A., Sullards, M. C. and Mandarino, L. J. (2004) Ceramide content is increased in skeletal muscle from obese insulin-resistant humans. Diabetes 53, 25-31.

Argraves, K. M., Sethi, A. A., Gazzolo, P. J., Wilkerson, B. A., Remaley, A. T., Tybjaerg-Hansen, A., Nordestgaard, B. G., Yeatts, S. D., Nicholas, K. S., Barth, J. L. and Argraves, W. S. (2011) S1P, dihydro-S1P and C24:1-ceramide levels in the HDL-containing fraction of serum inversely correlate with occurrence of ischemic heart disease. Lipids Health Dis. 10, 70.

Bergman, B. C., Brozinick, J. T., Strauss, A., Bacon, S., Kerege, A., Bui, H. H., Sanders, P., Siddall, P., Kuo, M. S. and Perreault, L. (2015) Serum sphingolipids: relationships to insulin sensitivity and changes with exercise in humans. Am. J. Physiol. Endocrinol. Metab. 309, E398-E408.

Bhunia, A. K., Han, H., Snowden, A. and Chatterjee, S. (1997) Redoxregulated signaling by lactosylceramide in the proliferation of human aortic smooth muscle cells. J. Biol. Chem. 272, 15642-15649.

Bietrix, F., Lombardo, E., van Roomen, C. P., Ottenhoff, R., Vos, M., Rensen, P. C., Verhoeven, A. J., Aerts, J. M. and Groen, A. K. (2010) Inhibition of glycosphingolipid synthesis induces a profound reduction of plasma cholesterol and inhibits atherosclerosis development in $\mathrm{APOE}^{*} 3$ Leiden and low-density lipoprotein receptor-/mice. Arterioscler. Thromb. Vasc. Biol. 30, 931-937.

Bikman, B. T., Guan, Y., Shui, G., Siddique, M. M., Holland, W. L., Kim, J. Y., Fabrias, G., Wenk, M. R. and Summers, S. A. (2012) Fenretinide prevents lipid-induced insulin resistance by blocking ceramide biosynthesis. J. Biol. Chem. 287, 17426-17437.

Blom, T., Back, N., Mutka, A. L., Bittman, R., Li, Z., de Lera, A., Kovanen, P. T., Diczfalusy, U. and Ikonen, E. (2010) FTY720 stimulates 27-hydroxycholesterol production and confers atheroprotective effects in human primary macrophages. Circ. Res. 106, 720729.

Bobryshev, Y. V., Lord, R. S., Golovanova, N. K., Gracheva, E. V., Zvezdina, N. D., Sadovskaya, V. L. and Prokazova, N. V. (1997) Incorporation and localisation of ganglioside GM3 in human intimal atherosclerotic lesions. Biochim. Biophys. Acta 1361, 287-294.

Boon, J., Hoy, A. J., Stark, R., Brown, R. D., Meex, R. C., Henstridge, D. C., Schenk, S., Meikle, P. J., Horowitz, J. F., Kingwell, B. A., Bruce, C. R. and Watt, M. J. (2013) Ceramides contained in LDL are elevated in type 2 diabetes and promote inflammation and skeletal muscle insulin resistance. Diabetes 62, 401-410.

Breckenridge, W. C., Halloran, J. L., Kovacs, K. and Silver, M. D. (1975) Increase of gangliosides in atherosclerotic human aortas. Lipids 10, 256-259.

Campana, M., Bellini, L., Rouch, C., Rachdi, L., Coant, N., Butin, N., Bandet, C. L., Philippe, E., Meneyrol, K., Kassis, N., Dairou, J., Hajduch, E., Colsch, B., Magnan, C. and Le Stunff, H. (2018) Inhibition of central de novo ceramide synthesis restores insulin signaling in hypothalamus and enhances beta-cell function of obese Zucker rats. Mol. Metab. 8, 23-36.

Castro, B. M., Prieto, M. and Silva, L. C. (2014) Ceramide: a simple sphingolipid with unique biophysical properties. Prog. Lipid Res. 54, 53-67.

Chatterjee, S., Bedja, D., Mishra, S., Amuzie, C., Avolio, A., Kass, D. A., Berkowitz, D. and Renehan, M. (2014) Inhibition of glycosphingolipid synthesis ameliorates atherosclerosis and arterial stiffness in apolipoprotein $\mathrm{E}^{-/}$mice and rabbits fed a high-fat and -cholesterol diet. Circulation 129, 2403-2413.

Chatterjee, S. B., Dey, S., Shi, W. Y., Thomas, K. and Hutchins, G. M. (1997) Accumulation of glycosphingolipids in human atherosclerotic plaque and unaffected aorta tissues. Glycobiology 7, 57-65.

Chaurasia, B. and Summers, S. A. (2015) Ceramides - lipotoxic inducers of metabolic disorders. Trends Endocrinol. Metab. 26, 538-550.

Chaurasia, B., Tippetts, T. S., Mayoral Monibas, R., Liu, J., Li, Y., Wang, L., Wilkerson, J. L., Sweeney, C. R., Pereira, R. F., Sumida, D. H., Maschek, J. A., Cox, J. E., Kaddai, V., Lancaster, G. I., Siddique, M. M., Poss, A., Pearson, M., Satapati, S., Zhou, H., McLaren, D. G., Previs, S. F., Chen, Y., Qian, Y., Petrov, A., Wu, M., Shen, X., Yao, J., Nunes, C. N., Howard, A. D., Wang, L., Erion, M. D., 
Rutter, J., Holland, W. L., Kelley, D. E. and Summers, S. A. (2019) Targeting a ceramide double bond improves insulin resistance and hepatic steatosis. Science 365, 386-392.

Chavez, J. A., Holland, W. L., Bar, J., Sandhoff, K. and Summers, S. A. (2005) Acid ceramidase overexpression prevents the inhibitory effects of saturated fatty acids on insulin signaling. J. Biol. Chem. 280, 20148-20153.

Chavez, J. A., Knotts, T. A., Wang, L. P., Li, G., Dobrowsky, R. T., Florant, G. L. and Summers, S. A. (2003) A role for ceramide, but not diacylglycerol, in the antagonism of insulin signal transduction by saturated fatty acids. J. Biol. Chem. 278, 10297-10303.

Chavez, J. A. and Summers, S. A. (2012) A ceramide-centric view of insulin resistance. Cell Metab. 15, 585-594.

Cheng, J. M., Suoniemi, M., Kardys, I., Vihervaara, T., de Boer, S. P., Akkerhuis, K. M., Sysi-Aho, M., Ekroos, K., Garcia-Garcia, H. M., Oemrawsingh, R. M., Regar, E., Koenig, W., Serruys, P. W., van Geuns, R. J., Boersma, E. and Laaksonen, R. (2015a) Plasma concentrations of molecular lipid species in relation to coronary plaque characteristics and cardiovascular outcome: results of the ATHEROREMO-IVUS study. Atherosclerosis 243, 560-566.

Cheng, L., Chen, Y. Z., Peng, Y., Yi, N., Gu, X. S., Jin, Y. and Bai, X. M. (2015b) Ceramide production mediates cinobufotalin-induced growth inhibition and apoptosis in cultured hepatocellular carcinoma cells. Tumour Biol. 36, 5763-5771.

de Mello, V. D., Lankinen, M., Schwab, U., Kolehmainen, M., Lehto, S., Seppanen-Laakso, T., Oresic, M., Pulkkinen, L., Uusitupa, M. and Erkkila, A. T. (2009) Link between plasma ceramides, inflammation and insulin resistance: association with serum IL-6 concentration in patients with coronary heart disease. Diabetologia 52, 2612-2615.

Dekker, M. J., Baker, C., Naples, M., Samsoondar, J., Zhang, R., Qiu, W., Sacco, J. and Adeli, K. (2013) Inhibition of sphingolipid synthesis improves dyslipidemia in the diet-induced hamster model of insulin resistance: evidence for the role of sphingosine and sphinganine in hepatic VLDL-apoB100 overproduction. Atherosclerosis 228, 98-109.

Delgado, A., Casas, J., Llebaria, A., Abad, J. L. and Fabrias, G. (2006) Inhibitors of sphingolipid metabolism enzymes. Biochim. Biophys. Acta 1758, 1957-1977.

Deutschman, D. H., Carstens, J. S., Klepper, R. L., Smith, W. S., Page, M. T., Young, T. R., Gleason, L. A., Nakajima, N. and Sabbadini, R. A. (2003) Predicting obstructive coronary artery disease with serum sphingosine-1-phosphate. Am. Heart J. 146, 62-68.

Devlin, C. M., Leventhal, A. R., Kuriakose, G., Schuchman, E. H., Williams, K. J. and Tabas, I. (2008) Acid sphingomyelinase promotes lipoprotein retention within early atheromata and accelerates lesion progression. Arterioscler. Thromb. Vasc. Biol. 28, 1723-1730.

Dong, J., Liu, J., Lou, B., Li, Z., Ye, X., Wu, M. and Jiang, X. C. (2006) Adenovirus-mediated overexpression of sphingomyelin synthases 1 and 2 increases the atherogenic potential in mice. J. Lipid Res. 47, 1307-1314.

Ebel, P., Imgrund, S., Vom Dorp, K., Hofmann, K., Maier, H., Drake, H., Degen, J., Dormann, P., Eckhardt, M., Franz, T. and Willecke, K. (2014) Ceramide synthase 4 deficiency in mice causes lipid alterations in sebum and results in alopecia. Biochem. J. 461, 147-158.

Ebel, P., Vom Dorp, K., Petrasch-Parwez, E., Zlomuzica, A., Kinugawa, K., Mariani, J., Minich, D., Ginkel, C., Welcker, J., Degen, J., Eckhardt, M., Dere, E., Dormann, P. and Willecke, K. (2013) Inactivation of ceramide synthase 6 in mice results in an altered sphingolipid metabolism and behavioral abnormalities. J. Biol. Chem. 288 21433-21447.

Fabbri, E., Yang, A., Simonsick, E. M., Chia, C. W., Zoli, M., Haughey, N. J., Mielke, M. M., Ferrucci, L. and Coen, P. M. (2016) Circulating ceramides are inversely associated with cardiorespiratory fitness in participants aged 54-96 years from the Baltimore Longitudinal Study of Aging. Aging Cell 15, 825-831.

Fettel, J., Kuhn, B., Guillen, N. A., Surun, D., Peters, M., Bauer, R., Angioni, C., Geisslinger, G., Schnutgen, F., Meyer Zu Heringdorf, D., Werz, O., Meybohm, P., Zacharowski, K., Steinhilber, D., Roos, J. and Maier, T. J. (2019) Sphingosine-1-phosphate (S1P) induces potent anti-inflammatory effects in vitro and in vivo by S1P receptor 4-mediated suppression of 5-lipoxygenase activity. FASEB J. $\mathbf{3 3}$ $1711-1726$
Gable, K., Slife, H., Bacikova, D., Monaghan, E. and Dunn, T. M. (2000) Tsc3p is an 80-amino acid protein associated with serine palmitoyltransferase and required for optimal enzyme activity. $J$. Biol. Chem. 275, 7597-7603.

Galadari, S., Rahman, A., Pallichankandy, S. and Thayyullathil, F. (2015) Tumor suppressive functions of ceramide: evidence and mechanisms. Apoptosis 20, 689-711.

Garner, B., Priestman, D. A., Stocker, R., Harvey, D. J., Butters, T. D. and Platt, F. M. (2002) Increased glycosphingolipid levels in serum and aortae of apolipoprotein E gene knockout mice. J. Lipid Res. 43, 205-214.

Gault, C. R., Obeid, L. M. and Hannun, Y. A. (2010) An overview of sphingolipid metabolism: from synthesis to breakdown. Adv. Exp. Med. Biol. 688, 1-23.

Glaros, E. N., Kim, W. S., Wu, B. J., Suarna, C., Quinn, C. M., Rye, K. A., Stocker, R., Jessup, W. and Garner, B. (2007) Inhibition of atherosclerosis by the serine palmitoyl transferase inhibitor myriocin is associated with reduced plasma glycosphingolipid concentration. Biochem. Pharmacol. 73, 1340-1346.

Gong, N., Wei, H., Chowdhury, S. H. and Chatterjee, S. (2004) Lactosylceramide recruits PKCalpha/epsilon and phospholipase A2 to stimulate PECAM-1 expression in human monocytes and adhesion to endothelial cells. Proc. Natl. Acad. Sci. U.S.A. 101, 6490-6495.

Gracheva, E. V., Samovilova, N. N., Golovanova, N. K., Kashirina, S. V., Shevelev, A., Rybalkin, I., Gurskaya, T., Vlasik, T. N., Andreeva, E. R. and Prokazova, N. V. (2009) Enhancing of GM3 synthase expression during differentiation of human blood monocytes into macrophages as in vitro model of GM3 accumulation in atherosclerotic lesion. Mol. Cell. Biochem. 330, 121-129.

Hailemariam, T. K., Huan, C., Liu, J., Li, Z., Roman, C., Kalbfeisch, M., Bui, H. H., Peake, D. A., Kuo, M. S., Cao, G., Wadgaonkar, R. and Jiang, X. C. (2008) Sphingomyelin synthase 2 deficiency attenuates NFkappaB activation. Arterioscler. Thromb. Vasc. Biol. 28, 1519-1526.

Hait, N. C., Oskeritzian, C. A., Paugh, S. W., Milstien, S. and Spiegel, S. (2006) Sphingosine kinases, sphingosine 1-phosphate, apoptosis and diseases. Biochim. Biophys. Acta 1758, 2016-2026.

Hammerschmidt, P., Ostkotte, D., Nolte, H., Gerl, M. J., Jais, A., Brunner, H. L., Sprenger, H. G., Awazawa, M., Nicholls, H. T., TurpinNolan, S. M., Langer, T., Kruger, M., Brugger, B. and Bruning, J. C. (2019) CerS6-derived sphingolipids interact with Mff and Promote mitochondrial fragmentation in obesity. Cell 177, 1536-1552.e23.

Hanada, K. (2003) Serine palmitoyltransferase, a key enzyme of sphingolipid metabolism. Biochim. Biophys. Acta 1632, 16-30.

Haus, J. M., Kashyap, S. R., Kasumov, T., Zhang, R., Kelly, K. R., Defronzo, R. A. and Kirwan, J. P. (2009) Plasma ceramides are elevated in obese subjects with type 2 diabetes and correlate with the severity of insulin resistance. Diabetes 58, 337-343.

Havulinna, A. S., Sysi-Aho, M., Hilvo, M., Kauhanen, D., Hurme, R., Ekroos, K., Salomaa, V. and Laaksonen, R. (2016) Circulating ceramides predict cardiovascular outcomes in the population-based FINRISK 2002 cohort. Arterioscler. Thromb. Vasc. Biol. 36, 24242430.

Hla, T. and Dannenberg, A. J. (2012) Sphingolipid signaling in metabolic disorders. Cell Metab. 16, 420-434.

Hla, T. and Kolesnick, R. (2014) C16:0-ceramide signals insulin resistance. Cell Metab. 20, 703-705.

Hojjati, M. R., Li, Z., Zhou, H., Tang, S., Huan, C., Ooi, E., Lu, S. and Jiang, X. C. (2005) Effect of myriocin on plasma sphingolipid metabolism and atherosclerosis in apoE-deficient mice. J. Biol. Chem. 280, 10284-10289.

Holland, W. L., Brozinick, J. T., Wang, L. P., Hawkins, E. D., Sargent, K. M., Liu, Y., Narra, K., Hoehn, K. L., Knotts, T. A., Siesky, A., Nelson, D. H., Karathanasis, S. K., Fontenot, G. K., Birnbaum, M. J. and Summers, S. A. (2007) Inhibition of ceramide synthesis ameliorates glucocorticoid-, saturated-fat-, and obesity-induced insulin resistance. Cell Metab. 5, 167-179.

Holland, W. L., Miller, R. A., Wang, Z. V., Sun, K., Barth, B. M., Bui, H. H., Davis, K. E., Bikman, B. T., Halberg, N., Rutkowski, J. M., Wade, M. R., Tenorio, V. M., Kuo, M. S., Brozinick, J. T., Zhang, B. B., Birnbaum, M. J., Summers, S. A. and Scherer, P. E. (2011) Receptor-mediated activation of ceramidase activity initiates the 
pleiotropic actions of adiponectin. Nat. Med. 17, 55-63.

Holland, W. L., Xia, J. Y., Johnson, J. A., Sun, K., Pearson, M. J., Sharma, A. X., Quittner-Strom, E., Tippetts, T. S., Gordillo, R. and Scherer, P. E. (2017) Inducible overexpression of adiponectin receptors highlight the roles of adiponectin-induced ceramidase signaling in lipid and glucose homeostasis. Mol. Metab. 6, 267-275.

Hornemann, T., Richard, S., Rutti, M. F., Wei, Y. and von Eckardstein, A. (2006) Cloning and initial characterization of a new subunit for mammalian serine-palmitoyltransferase. J. Biol. Chem. 281, 37275-37281

Imgrund, S., Hartmann, D., Farwanah, H., Eckhardt, M., Sandhoff, R. Degen, J., Gieselmann, V., Sandhoff, K. and Willecke, K. (2009) Adult ceramide synthase 2 (CERS2)-deficient mice exhibit myelin sheath defects, cerebellar degeneration, and hepatocarcinomas. J. Biol. Chem. 284, 33549-33560.

Jennemann, R., Rabionet, M., Gorgas, K., Epstein, S., Dalpke, A., Rothermel, U., Bayerle, A., van der Hoeven, F., Imgrund, S., Kirsch, J., Nickel, W., Willecke, K., Riezman, H., Grone, H. J. and Sandhoff, R. (2012) Loss of ceramide synthase 3 causes lethal skin barrier disruption. Hum. Mol. Genet. 21, 586-608.

Jiang, X. C., Paultre, F., Pearson, T. A., Reed, R. G., Francis, C. K., Lin, M., Berglund, L. and Tall, A. R. (2000) Plasma sphingomyelin level as a risk factor for coronary artery disease. Arterioscler. Thromb. Vasc. Biol. 20, 2614-2618.

Jiao, G. Q., Yuan, Z. X., Xue, Y. S., Yang, C. J., Lu, C. B., Lu, Z. Q. and Xiao, M. D. (2007) A prospective evaluation of apolipoprotein M gene T-778C polymorphism in relation to coronary artery disease in Han Chinese. Clin. Biochem. 40, 1108-1112.

Jin, J., Zhang, X., Lu, Z., Perry, D. M., Li, Y., Russo, S. B., Cowart, L. A., Hannun, Y. A. and Huang, Y. (2013) Acid sphingomyelinase plays a key role in palmitic acid-amplified inflammatory signaling triggered by lipopolysaccharide at low concentrations in macrophages. Am. J. Physiol. Endocrinol. Metab. 305, E853-E867.

Johansson, H., Gandini, S., Guerrieri-Gonzaga, A., lodice, S., Ruscica, M., Bonanni, B., Gulisano, M., Magni, P., Formelli, F. and Decensi, A. (2008) Effect of fenretinide and low-dose tamoxifen on insulin sensitivity in premenopausal women at high risk for breast cancer. Cancer. Res. 68, 9512-9518.

Kasumov, T., Li, L., Li, M., Gulshan, K., Kirwan, J. P., Liu, X., Previs S., Willard, B., Smith, J. D. and McCullough, A. (2015) Ceramide as a mediator of non-alcoholic Fatty liver disease and associated atherosclerosis. PLoS ONE 10, e0126910.

Keul, P., Lucke, S., von Wnuck Lipinski, K., Bode, C., Graler, M., Heusch, G. and Levkau, B. (2011) Sphingosine-1-phosphate receptor 3 promotes recruitment of monocyte/macrophages in inflammation and atherosclerosis. Circ. Res. 108, 314-323.

Keul, P., Tolle, M., Lucke, S., von Wnuck Lipinski, K., Heusch, G. Schuchardt, M., van der Giet, M. and Levkau, B. (2007) The sphingosine-1-phosphate analogue FTY720 reduces atherosclerosis in apolipoprotein E-deficient mice. Arterioscler. Thromb. Vasc. Biol. 27, 607-613.

Knapp, M., Baranowski, M., Czarnowski, D., Lisowska, A., Zabielski, P., Gorski, J. and Musial, W. (2009) Plasma sphingosine-1-phosphate concentration is reduced in patients with myocardial infarction. Med. Sci. Monit. 15, CR490-CR493.

Knapp, M., Lisowska, A., Zabielski, P., Musial, W. and Baranowski, M. (2013) Sustained decrease in plasma sphingosine-1-phosphate concentration and its accumulation in blood cells in acute myocardial infarction. Prostaglandins Other Lipid Mediat. 106, 53-61.

Koh, I. U., Jun, H. S., Choi, J. S., Lim, J. H., Kim, W. H., Yoon, J. B. and Song, J. (2012) Fenretinide ameliorates insulin resistance and fatty liver in obese mice. Biol. Pharm. Bull. 35, 369-375.

Kolesnick, R. (2002) The therapeutic potential of modulating the ceramide/sphingomyelin pathway. J. Clin. Invest. 110, 3-8.

Kraveka, J. M., Li, L., Szulc, Z. M., Bielawski, J., Ogretmen, B., Hannun, Y. A., Obeid, L. M. and Bielawska, A. (2007) Involvement of dihydroceramide desaturase in cell cycle progression in human neuroblastoma cells. J. Biol. Chem. 282, 16718-16728.

Kurano, M. and Yatomi, Y. (2018) Sphingosine 1-phosphate and atherosclerosis. J. Atheroscler. Thromb. 25, 16-26.

Kurek, K., Piotrowska, D. M., Wiesiolek-Kurek, P., Lukaszuk, B., Chabowski, A., Gorski, J. and Zendzian-Piotrowska, M. (2014)
Inhibition of ceramide de novo synthesis reduces liver lipid accumulation in rats with nonalcoholic fatty liver disease. Liver Int. 34, 1074-1083.

Laaksonen, R., Ekroos, K., Sysi-Aho, M., Hilvo, M., Vihervaara, T., Kauhanen, D., Suoniemi, M., Hurme, R., Marz, W., Scharnagl, H., Stojakovic, T., Vlachopoulou, E., Lokki, M. L., Nieminen, M. S., Klingenberg, R., Matter, C. M., Hornemann, T., Juni, P., Rodondi, N., Raber, L., Windecker, S., Gencer, B., Pedersen, E. R., Tell, G. S., Nygard, O., Mach, F., Sinisalo, J. and Luscher, T. F. (2016) Plasma ceramides predict cardiovascular death in patients with stable coronary artery disease and acute coronary syndromes beyond LDL-cholesterol. Eur. Heart J. 37, 1967-1976.

Lallemand, T., Rouahi, M., Swiader, A., Grazide, M. H., Geoffre, N., Alayrac, P., Recazens, E., Coste, A., Salvayre, R., Negre-Salvayre, A. and Auge, N. (2018) nSMase2 (type 2-neutral sphingomyelinase) deficiency or inhibition by GW4869 reduces inflammation and atherosclerosis in Apoe(-/-) mice. Arterioscler. Thromb. Vasc. Biol. 38, 1479-1492.

Lemaitre, R. N., Yu, C., Hoofnagle, A., Hari, N., Jensen, P. N., Fretts, A. M., Umans, J. G., Howard, B. V., Sitlani, C. M., Siscovick, D. S., King, I. B., Sotoodehnia, N. and McKnight, B. (2018) Circulating sphingolipids, insulin, HOMA-IR, and HOMA-B: the Strong Heart Family Study. Diabetes 67, 1663-1672.

Li, M., Markham, J. E. and Wang, X. (2014) Overexpression of patatinrelated phospholipase Alllbeta altered the content and composition of sphingolipids in Arabidopsis. Front. Plant Sci. 5, 553.

Li, Z., Fan, Y., Liu, J., Li, Y., Huan, C., Bui, H. H., Kuo, M. S., Park, T. S., Cao, G. and Jiang, X. C. (2012) Impact of sphingomyelin synthase 1 deficiency on sphingolipid metabolism and atherosclerosis in mice. Arterioscler. Thromb. Vasc. Biol. 32, 1577-1584.

Liu, J., Huan, C., Chakraborty, M., Zhang, H., Lu, D., Kuo, M. S., Cao, G. and Jiang, X. C. (2009) Macrophage sphingomyelin synthase 2 deficiency decreases atherosclerosis in mice. Circ. Res. 105, 295303.

Liu, Y., Wada, R., Yamashita, T., Mi, Y., Deng, C. X., Hobson, J. P., Rosenfeldt, H. M., Nava, V. E., Chae, S. S., Lee, M. J., Liu, C. H., Hla, T., Spiegel, S. and Proia, R. L. (2000) Edg-1, the G proteincoupled receptor for sphingosine-1-phosphate, is essential for vascular maturation. J. Clin. Invest. 106, 951-961.

Lopez, X., Goldfine, A. B., Holland, W. L., Gordillo, R. and Scherer, P. E. (2013) Plasma ceramides are elevated in female children and adolescents with type 2 diabetes. J. Pediatr. Endocrinol. Metab. 26, 995-998

Lozano, R., Naghavi, M., Foreman, K., Lim, S., Shibuya, K., Aboyans, V., Abraham, J., Adair, T., Aggarwal, R., Ahn, S. Y., Alvarado, M., Anderson, H. R., Anderson, L. M., Andrews, K. G., Atkinson, C., Baddour, L. M., Barker-Collo, S., Bartels, D. H., Bell, M. L., Benjamin, E. J., Bennett, D., Bhalla, K., Bikbov, B., Bin Abdulhak, A., Birbeck, G., Blyth, F., Bolliger, I., Boufous, S., Bucello, C., Burch, M., Burney, P., Carapetis, J., Chen, H., Chou, D., Chugh, S. S., Coffeng, L. E., Colan, S. D., Colquhoun, S., Colson, K. E., Condon, J., Connor, M. D., Cooper, L. T., Corriere, M., Cortinovis, M., de Vaccaro, K. C., Couser, W., Cowie, B. C., Criqui, M. H., Cross, M., Dabhadkar, K. C., Dahodwala, N., De Leo, D., Degenhardt, L., Delossantos, A., Denenberg, J., Des Jarlais, D. C., Dharmaratne, S. D., Dorsey, E. R., Driscoll, T., Duber, H., Ebel, B., Erwin, P. J., Espindola, P., Ezzati, M., Feigin, V., Flaxman, A. D., Forouzanfar, M. H., Fowkes, F. G., Franklin, R., Fransen, M., Freeman, M. K., Gabriel, S. E., Gakidou, E., Gaspari, F., Gillum, R. F., Gonzalez-Medina, D., Halasa, Y. A., Haring, D., Harrison, J. E., Havmoeller, R., Hay, R. J., Hoen, B., Hotez, P. J., Hoy, D., Jacobsen, K. H., James, S. L., Jasrasaria, R., Jayaraman, S., Johns, N., Karthikeyan, G., Kassebaum, N., Keren, A., Khoo, J. P., Knowlton, L. M., Kobusingye, O., Koranteng, A., Krishnamurthi, R., Lipnick, M., Lipshultz, S. E., Ohno, S. L., Mabweijano, J., Maclntyre, M. F., Mallinger, L., March, L., Marks, G. B., Marks, R., Matsumori, A., Matzopoulos, R., Mayosi, B. M., McAnulty, J. H., McDermott, M. M., McGrath, J., Mensah, G. A., Merriman, T. R., Michaud, C., Miller, M., Miller, T. R., Mock, C., Mocumbi, A. O., Mokdad, A. A., Moran, A., Mulholland, K., Nair, M. N., Naldi, L., Narayan, K. M., Nasseri, K., Norman, P., O'Donnell, M., Omer, S. B., Ortblad, K., Osborne, R., Ozgediz, D., Pahari, B., Pandian, J. D., Rivero, A. P., Padilla, R. P., Perez-Ruiz, 
F., Perico, N., Phillips, D., Pierce, K., Pope, C. A., 3rd, Porrini, E., Pourmalek, F., Raju, M., Ranganathan, D., Rehm, J. T., Rein, D. B., Remuzzi, G., Rivara, F. P., Roberts, T., De Leon, F. R., Rosenfeld, L. C., Rushton, L., Sacco, R. L., Salomon, J. A., Sampson, U., Sanman, E., Schwebel, D. C., Segui-Gomez, M., Shepard, D. S., Singh, D., Singleton, J., Sliwa, K., Smith, E., Steer, A., Taylor, J. A., Thomas, B., Tleyjeh, I. M., Towbin, J. A., Truelsen, T., Undurraga, E. A., Venketasubramanian, N., Vijayakumar, L., Vos, T., Wagner, G. R., Wang, M., Wang, W., Watt, K., Weinstock, M. A., Weintraub, R., Wilkinson, J. D., Woolf, A. D., Wulf, S., Yeh, P. H., Yip, P., Zabetian, A., Zheng, Z. J., Lopez, A. D., Murray, C. J., AlMazroa, M. A. and Memish, Z. A. (2012) Global and regional mortality from 235 causes of death for 20 age groups in 1990 and 2010: a systematic analysis for the Global Burden of Disease Study 2010. Lancet 380, 2095-2128.

Maceyka, M. and Spiegel, S. (2014) Sphingolipid metabolites in inflammatory disease. Nature 510, 58-67.

Manicke, N. E., Nefliu, M., Wu, C., Woods, J. W., Reiser, V., Hendrickson, R. C. and Cooks, R. G. (2009) Imaging of lipids in atheroma by desorption electrospray ionization mass spectrometry. Anal. Chem. 81, 8702-8707.

Marathe, S., Kuriakose, G., Williams, K. J. and Tabas, I. (1999) Sphingomyelinase, an enzyme implicated in atherogenesis, is present in atherosclerotic lesions and binds to specific components of the subendothelial extracellular matrix. Arterioscler. Thromb. Vasc. Biol. 19, 2648-2658.

Maula, T., Al Sazzad, M. A. and Slotte, J. P. (2015) Influence of hydroxylation, chain length, and chain unsaturation on bilayer properties of ceramides. Biophys. J. 109, 1639-1651.

Meeusen, J. W., Donato, L. J., Bryant, S. C., Baudhuin, L. M., Berger, P. B. and Jaffe, A. S. (2018) Plasma ceramides. Arterioscler. Thromb. Vasc. Biol. 38, 1933-1939.

Meikle, P. J., Wong, G., Tsorotes, D., Barlow, C. K., Weir, J. M., Christopher, M. J., MacIntosh, G. L., Goudey, B., Stern, L., Kowalczyk, A., Haviv, I., White, A. J., Dart, A. M., Duffy, S. J., Jennings, G. L. and Kingwell, B. A. (2011) Plasma lipidomic analysis of stable and unstable coronary artery disease. Arterioscler. Thromb. Vasc. Biol. 31, 2723-2732.

Merrill, A. H., Jr. (2002) De novo sphingolipid biosynthesis: a necessary, but dangerous, pathway. J. Biol. Chem. 277, 25843-25846.

Michaud, J., Im, D. S. and Hla, T. (2010) Inhibitory role of sphingosine 1-phosphate receptor 2 in macrophage recruitment during inflammation. J. Immunol. 184, 1475-1483.

Mody, N. and Mcllroy, G. D. (2014) The mechanisms of Fenretinidemediated anti-cancer activity and prevention of obesity and type-2 diabetes. Biochem. Pharmacol. 91, 277-286.

Mukhin, D. N., Chao, F. F. and Kruth, H. S. (1995) Glycosphingolipid accumulation in the aortic wall is another feature of human atherosclerosis. Arterioscler. Thromb. Vasc. Biol. 15, 1607-1615.

Munoz-Olaya, J. M., Matabosch, X., Bedia, C., Egido-Gabas, M., Casas, J., Llebaria, A., Delgado, A. and Fabrias, G. (2008) Synthesis and biological activity of a novel inhibitor of dihydroceramide desaturase. ChemMedChem 3, 946-953.

Murray, C. J. and Lopez, A. D. (1997) Mortality by cause for eight regions of the world: Global Burden of Disease Study. Lancet $\mathbf{3 4 9}$ 1269-1276.

Neeland, I. J., Singh, S., McGuire, D. K., Vega, G. L., Roddy, T., Reilly, D. F., Castro-Perez, J., Kozlitina, J. and Scherer, P. E. (2018) Relation of plasma ceramides to visceral adiposity, insulin resistance and the development of type 2 diabetes mellitus: the Dallas Heart Study. Diabetologia 61, 2570-2579.

Nicholls, M. (2017) Plasma ceramides and cardiac risk. Eur. Heart J. 38, 1359-1360.

Omae, F., Miyazaki, M., Enomoto, A., Suzuki, M., Suzuki, Y. and Suzuki, A. (2004) DES2 protein is responsible for phytoceramide biosynthesis in the mouse small intestine. Biochem. J. 379, 687-695.

Pan, W., Yu, J., Shi, R., Yan, L., Yang, T., Li, Y., Zhang, Z., Yu, G., Bai, Y., Schuchman, E. H., He, X. and Zhang, G. (2014) Elevation of ceramide and activation of secretory acid sphingomyelinase in patients with acute coronary syndromes. Coron. Artery Dis. 25, 230-235.

Park, J. W., Park, W. J. and Futerman, A. H. (2014) Ceramide syn- thases as potential targets for therapeutic intervention in human diseases. Biochim. Biophys. Acta 1841, 671-681.

Park, T. S., Panek, R. L., Mueller, S. B., Hanselman, J. C., Rosebury, W. S., Robertson, A. W., Kindt, E. K., Homan, R., Karathanasis, S. K. and Rekhter, M. D. (2004) Inhibition of sphingomyelin synthesis reduces atherogenesis in apolipoprotein E-knockout mice. Circulation 110, 3465-3471.

Park, T. S., Panek, R. L., Rekhter, M. D., Mueller, S. B., Rosebury, W. S., Robertson, A., Hanselman, J. C., Kindt, E., Homan, R. and Karathanasis, S. K. (2006) Modulation of lipoprotein metabolism by inhibition of sphingomyelin synthesis in ApoE knockout mice. Atherosclerosis 189, 264-272.

Park, T. S., Rosebury, W., Kindt, E. K., Kowala, M. C. and Panek, R. L. (2008) Serine palmitoyltransferase inhibitor myriocin induces the regression of atherosclerotic plaques in hyperlipidemic ApoEdeficient mice. Pharmacol. Res. 58, 45-51.

Peterson, L. R., Xanthakis, V., Duncan, M. S., Gross, S., Friedrich, N., Völzke, H., Felix, S. B., Jiang, H., Sidhu, R., Nauck, M., Jiang, X., Ory, D. S., Dörr, M., Vasan, R. S. and Schaffer, J. E. (2018) Ceramide remodeling and risk of cardiovascular events and mortality. J. Am. Heart Assoc. 7, e007931.

Pewzner-Jung, Y., Ben-Dor, S. and Futerman, A. H. (2006) When do Lasses (longevity assurance genes) become CerS (ceramide synthases)?: insights into the regulation of ceramide synthesis. J. Biol. Chem. 281, 25001-25005.

Polzin, A., Piayda, K., Keul, P., Dannenberg, L., Mohring, A., Graler, M., Zeus, T., Kelm, M. and Levkau, B. (2017) Plasma sphingosine1-phosphate concentrations are associated with systolic heart failure in patients with ischemic heart disease. J. Mol. Cell. Cardiol. $110,35-37$.

Portman, O. W. and Alexander, M. (1970) Metabolism of sphingolipids by normal and atherosclerotic aorta of squirrel monkeys. J. Lipid Res. 11, 23-30.

Poti, F., Ceglarek, U., Burkhardt, R., Simoni, M. and Nofer, J. R. (2015) SKI-II--a sphingosine kinase 1 inhibitor--exacerbates atherosclerosis in low-density lipoprotein receptor-deficient $\left(\mathrm{LDL}-\mathrm{R}^{-/}\right)$mice on high cholesterol diet. Atherosclerosis 240, 212-215.

Poti, F., Gualtieri, F., Sacchi, S., Weissen-Plenz, G., Varga, G., Brodde, M., Weber, C., Simoni, M. and Nofer, J. R. (2013) KRP203, sphingosine 1-phosphate receptor type 1 agonist, ameliorates atherosclerosis in LDL-R ${ }^{-/ /}$mice. Arterioscler. Thromb. Vasc. Biol. 33, 1505-1512.

Preitner, F., Mody, N., Graham, T. E., Peroni, O. D. and Kahn, B. B. (2009) Long-term Fenretinide treatment prevents high-fat dietinduced obesity, insulin resistance, and hepatic steatosis. Am. J. Physiol. Endocrinol. Metab. 297, E1420-E1429.

Prokazova, N. V., Mikhailenko, I. A. and Bergelson, L. D. (1991) Ganglioside GM3 stimulates the uptake and processing of low density lipoproteins by macrophages. Biochem. Biophys. Res. Commun. $177,582-587$.

Reibe-Pal, S. and Febbraio, M. A. (2017) Adiponectin serenades ceramidase to improve metabolism. Mol. Metab. 6, 233-235.

Rodriguez-Cuenca, S., Barbarroja, N. and Vidal-Puig, A. (2015) Dihydroceramide desaturase 1 , the gatekeeper of ceramide induced lipotoxicity. Biochim. Biophys. Acta 1851, 40-50.

Sasset, L., Zhang, Y., Dunn, T. M. and Di Lorenzo, A. (2016) Sphingolipid de novo biosynthesis: a rheostat of cardiovascular homeostasis. Trends Endocrinol. Metab. 27, 807-819.

Sattler, K., Lehmann, I., Graler, M., Brocker-Preuss, M., Erbel, R., Heusch, G. and Levkau, B. (2014) HDL-bound sphingosine 1-phosphate (S1P) predicts the severity of coronary artery atherosclerosis. Cell. Physiol. Biochem. 34, 172-184.

Sattler, K. J., Elbasan, S., Keul, P., Elter-Schulz, M., Bode, C., Graler, M. H., Brocker-Preuss, M., Budde, T., Erbel, R., Heusch, G. and Levkau, B. (2010) Sphingosine 1-phosphate levels in plasma and HDL are altered in coronary artery disease. Basic Res. Cardiol. $105,821-832$.

Schissel, S. L., Tweedie-Hardman, J., Rapp, J. H., Graham, G., Williams, K. J. and Tabas, I. (1996) Rabbit aorta and human atherosclerotic lesions hydrolyze the sphingomyelin of retained low-density lipoprotein. Proposed role for arterial-wall sphingomyelinase in subendothelial retention and aggregation of atherogenic lipopro- 
teins. J. Clin. Invest. 98, 1455-1464.

Sigruener, A., Kleber, M. E., Heimerl, S., Liebisch, G., Schmitz, G. and Maerz, W. (2014) Glycerophospholipid and sphingolipid species and mortality: the Ludwigshafen Risk and Cardiovascular Health (LURIC) study. PLOS ONE 9, e85724.

Skoura, A., Michaud, J., Im, D. S., Thangada, S., Xiong, Y., Smith, J. D. and Hla, T. (2011) Sphingosine-1-phosphate receptor-2 function in myeloid cells regulates vascular inflammation and atherosclerosis. Arterioscler. Thromb. Vasc. Biol. 31, 81-85.

Smith, E. B. (1960) Intimal and medial lipids in human aortas. Lancet 1, 799-803.

Summers, S. A. (2018) Could ceramides become the new cholesterol? Cell Metab. 27, 276-280.

Takahashi, C., Kurano, M., Nishikawa, M., Kano, K., Dohi, T., Miyauchi, K., Daida, H., Shimizu, T., Aoki, J. and Yatomi, Y. (2017) Vehicle-dependent Effects of Sphingosine 1-phosphate on Plasminogen Activator Inhibitor-1 Expression. J. Atheroscler. Thromb. 24, 954-969.

Tarasov, K., Ekroos, K., Suoniemi, M., Kauhanen, D., Sylvanne, T., Hurme, R., Gouni-Berthold, I., Berthold, H. K., Kleber, M. E., Laaksonen, R. and Marz, W. (2014) Molecular lipids identify cardiovascular risk and are efficiently lowered by simvastatin and PCSK9 deficiency. J. Clin. Endocrinol. Metab. 99, E45-E52.

Theilmeier, G., Schmidt, C., Herrmann, J., Keul, P., Schafers, M., Herrgott, I., Mersmann, J., Larmann, J., Hermann, S., Stypmann, J., Schober, O., Hildebrand, R., Schulz, R., Heusch, G., Haude, M., von Wnuck Lipinski, K., Herzog, C., Schmitz, M., Erbel, R., Chun, J. and Levkau, B. (2006) High-density lipoproteins and their constituent, sphingosine-1-phosphate, directly protect the heart against ischemia/reperfusion injury in vivo via the S1P3 lysophospholipid receptor. Circulation 114, 1403-1409.

Turpin, S. M., Nicholls, H. T., Willmes, D. M., Mourier, A., Brodesser, S., Wunderlich, C. M., Mauer, J., Xu, E., Hammerschmidt, P., Bronneke, H. S., Trifunovic, A., LoSasso, G., Wunderlich, F. T., Kornfeld, J. W., Bluher, M., Kronke, M. and Bruning, J. C. (2014) Obesityinduced CerS6-dependent C16:0 ceramide production promotes weight gain and glucose intolerance. Cell Metab. 20, 678-686.

Walters, M. J. and Wrenn, S. P. (2008) Effect of sphingomyelinasemediated generation of ceramide on aggregation of low-density lipoprotein. Langmuir 24, 9642-9647.

Wang, D. D., Toledo, E., Hruby, A., Rosner, B. A., Willett, W. C., Sun, Q., Razquin, C., Zheng, Y., Ruiz-Canela, M., Guasch-Ferre, M., Corella, D., Gomez-Gracia, E., Fiol, M., Estruch, R., Ros, E., Lapetra, J., Fito, M., Aros, F., Serra-Majem, L., Lee, C. H., Clish, C. B., Liang, L., Salas-Salvado, J., Martinez-Gonzalez, M. A. and Hu, F. B. (2017) Plasma ceramides, mediterranean diet, and incident cardiovascular disease in the PREDIMED Trial (Prevencion con Dieta Mediterranea). Circulation 135, 2028-2040.

Wang, G., Kim, R. Y., Imhof, I., Honbo, N., Luk, F. S., Li, K., Kumar, N., Zhu, B. Q., Eberle, D., Ching, D., Karliner, J. S. and Raffai, R. L. (2014) The immunosuppressant FTY720 prolongs survival in a mouse model of diet-induced coronary atherosclerosis and myocardial infarction. J. Cardiovasc. Pharmacol. 63, 132-143.

Wang, X., Dong, J., Zhao, Y., Li, Y. and Wu, M. (2011) Adenovirus-mediated sphingomyelin synthase 2 increases atherosclerotic lesions in ApoE KO mice. Lipids Health Dis. 10, 7.

Wigger, L., Cruciani-Guglielmacci, C., Nicolas, A., Denom, J., Fernandez, N., Fumeron, F., Marques-Vidal, P., Ktorza, A., Kramer, W.
Schulte, A., Le Stunff, H., Liechti, R., Xenarios, I., Vollenweider, P., Waeber, G., Uphues, I., Roussel, R., Magnan, C., Ibberson, M. and Thorens, B. (2017) Plasma dihydroceramides are diabetes susceptibility biomarker candidates in mice and humans. Cell Rep. 18, 2269-2279.

Wolfrum, C., Poy, M. N. and Stoffel, M. (2005) Apolipoprotein M is required for prebeta-HDL formation and cholesterol efflux to HDL and protects against atherosclerosis. Nat. Med. 11, 418-422.

Xia, J. Y., Holland, W. L., Kusminski, C. M., Sun, K., Sharma, A. X., Pearson, M. J., Sifuentes, A. J., McDonald, J. G., Gordillo, R. and Scherer, P. E. (2015) Targeted induction of ceramide degradation leads to improved systemic metabolism and reduced hepatic steatosis. Cell Metab. 22, 266-278.

Xu, W. W., Zhang, Y., Tang, Y. B., Xu, Y. L., Zhu, H. Z., Ferro, A., Ji, Y., Chen, Q. and Fan, L. M. (2008) A genetic variant of apolipoprotein $M$ increases susceptibility to coronary artery disease in a Chinese population. Clin. Exp. Pharmacol. Physiol. 35, 546-551.

Yu, J., Pan, W., Shi, R., Yang, T., Li, Y., Yu, G., Bai, Y., Schuchman, E. H., He, X. and Zhang, G. (2015) Ceramide is upregulated and associated with mortality in patients with chronic heart failure. Can. J. Cardiol. 31, 357-363.

Zabielski, P., Daniluk, J., Hady, H. R., Markowski, A. R., Imierska, M., Gorski, J. and Blachnio-Zabielska, A. U. (2019) The effect of highfat diet and inhibition of ceramide production on insulin action in liver. J. Cell. Physiol. 234, 1851-1861.

Zhang, Q. J., Holland, W. L., Wilson, L., Tanner, J. M., Kearns, D., Cahoon, J. M., Pettey, D., Losee, J., Duncan, B., Gale, D., Kowalski, C. A., Deeter, N., Nichols, A., Deesing, M., Arrant, C., Ruan, T., Boehme, C., McCamey, D. R., Rou, J., Ambal, K., Narra, K. K., Summers, S. A., Abel, E. D. and Symons, J. D. (2012) Ceramide mediates vascular dysfunction in diet-induced obesity by PP2Amediated dephosphorylation of the eNOS-Akt complex. Diabetes 61, 1848-1859.

Zhao, L., Spassieva, S. D., Jucius, T. J., Shultz, L. D., Shick, H. E., Macklin, W. B., Hannun, Y. A., Obeid, L. M. and Ackerman, S. L. (2011) A deficiency of ceramide biosynthesis causes cerebellar purkinje cell neurodegeneration and lipofuscin accumulation. PLoS Genet. 7, e1002063.

Zhao, M., Pan, W., Shi, R. Z., Bai, Y. P., You, B. Y., Zhang, K., Fu, Q. M., Schuchman, E. H., He, X. X. and Zhang, G. G. (2016) Acid sphingomyelinase mediates oxidized-LDL induced apoptosis in macrophage via endoplasmic reticulum stress. J. Atheroscler. Thromb. 23, 1111-1125.

Zhao, Y. R., Dong, J. B., Li, Y. and Wu, M. P. (2012) Sphingomyelin synthase 2 over-expression induces expression of aortic inflammatory biomarkers and decreases circulating EPCs in ApoE KO mice. Life Sci. 90, 867-873.

Zheng, W., Kollmeyer, J., Symolon, H., Momin, A., Munter, E., Wang, E., Kelly, S., Allegood, J. C., Liu, Y., Peng, Q., Ramaraju, H., Sullards, M. C., Cabot, M. and Merrill, A. H., Jr. (2006) Ceramides and other bioactive sphingolipid backbones in health and disease: lipidomic analysis, metabolism and roles in membrane structure, dynamics, signaling and autophagy. Biochim. Biophys. Acta 1758, 1864-1884.

Zilversmit, D. B., Mc, C. E., Jordan, P. H., Henly, W. S. and Ackerman, R. F. (1961) The synthesis of phospholipids in human atheromatous lesions. Circulation 23, 370-375. 